\title{
3及-Hydroxysteroid dehydrogenase activity and gestagen concentrations in bovine cotyledons and caruncles during gestation and parturition
}

\author{
S. Tsumagari, J. Kamata, K. Takagi, K. Tanemura, A. Yosai and \\ M. Takeishi \\ Department of Veterinary Obstetrics and Gynecology, Nihon University, 1866 Kameino, Fujisawa, \\ Kanagawa 252, Japan
}

\begin{abstract}
$3 \beta$-Hydroxysteroid dehydrogenase $(3 \beta-\mathrm{HSD})$ activity in bovine cotyledons was much higher than in caruncles throughout the gestation period. The activity of this enzyme in cotyledons increased greatly to $150.6 \pm 5.8 \mathrm{pmol} \mathrm{min}^{-1} \mathrm{mg}^{-1}$ protein during the seventh month of gestation, reached a peak of $221.0 \pm 34.9 \mathrm{pmol} \mathrm{min}^{-1} \mathrm{mg}^{-1}$ protein during the eighth month, and decreased at parturition. Progesterone and $20 \alpha$-hydroxyprogesterone concentrations in cotyledons also increased sharply to $2.69 \pm 0.30$ and $2.15 \pm 0.42 \mathrm{ng}$ $\mathrm{mg}^{-1}$ protein, respectively, during the seventh month of gestation, reaching peaks of $2.86 \pm 0.47$ and $2.51 \pm 0.36 \mathrm{ng} \mathrm{mg}^{-1}$ protein, respectively, during the eighth month and decreasing at parturition, in a manner similar to the activity of $3 \beta$-hydroxysteroid dehydrogenase. The fluctuation of $17 \alpha$-hydroxyprogesterone concentration in cotyledons was different from that of progesterone and $20 \alpha$-hydroxyprogesterone. These findings indicate that the activity of $3 \beta$-hydroxysteroid dehydrogenase in the placenta is enhanced during the third trimester, and progesterone synthesized in the cotyledons is converted concurrently to $20 \alpha$-hydroxyprogesterone before progesterone is transferred to the fetal blood.
\end{abstract}

\section{Introduction}

It has been reported that progesterone is not produced in the bovine placenta, as bovine uterine arteriovenous progesterone concentrations do not alter in this tissue (Comline et al., 1974; Ferrell et al., 1983). However, many other studies (Ainsworth and Ryan, 1967; Wiener, 1976; Inaba et al., 1983; Reimers et al., 1985; Conley and Ford, 1987) have demonstrated and confirmed progesterone synthesis in tissue cultures of placentae. In contrast to the attenuation in the function of bovine corpora lutea during the second half of gestation (Erb et al., 1968; Shemesh et al., 1983), progesterone concentration in the blood has been shown to increase substantially near term (Short, 1958; Stabenfeldt $e t$ al., 1970). Such an increase in the progesterone concentration during late gestation has been attributed to production by the placenta (Gomes and Erb, 1965; Stabenfeldt et al., 1970) and the adrenals (Wendrof et al., 1983). However, our knowledge of gestagen synthesis in the bovine placenta is limited. The aim of this study was to investigate progesterone synthesis in both cotyledons and caruncles by measuring the synthesis-

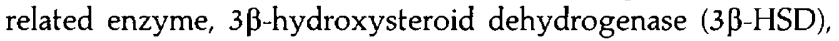
and gestagen concentrations in the placenta with respect to the stage of gestation.

\section{Materials and Methods}

\section{Animals and treatments}

Cotyledons and caruncles were isolated from 32 Holstein cows ( 28 gestations and four normal parturitions). The number of cows examined during gestation months 4-9 and at parturition was $4,4,4,6,5,5$ and 4 , respectively. The cotyledons and caruncles were separated manually within $30 \mathrm{~min}$ of slaughter or parturition. These isolated placentae were washed with cold physiological saline and were frozen immediately with dry ice and stored at $-80^{\circ} \mathrm{C}$ until assayed. The stage of gestation was estimated by determining fetal crown-rump length (Arthur et al., 1982).

\section{Assay of $3 \beta-H S D$ activity}

Determination of enzymatic activity was based on the substrate metabolism methods of Seki et al. (1987) and Hirato et al. (1982). $\left[{ }^{14} \mathrm{C}\right]$ Pregnenolone (specific activity, $57.2 \mathrm{Ci}$ $\mathrm{mmol}^{-1}$ ) was obtained from New England Nuclear Co. (Boston, USA). NAD was purchased from Oriental Koubo (Tokyo). Cotyledons and caruncles were homogenized in nine volumes of $0.25 \mathrm{~mol}$ sucrose-phosphate buffer $1^{-1}$ in a Teflon-glass homogenizer (Braun Melsungen, Wendelsteinstr., 
Germany) at 1000 r.p.m. for 45 s. Enzyme preparations (microsomal fraction) were obtained after centrifugation at $10000 \mathrm{~g}$ for $15 \mathrm{~min}$ at $4^{\circ} \mathrm{C}$ from the supernatant, which was then re-centrifuged at $105000 \mathrm{~g}$ for $\mathrm{I} \mathrm{h}$ at $4^{\circ} \mathrm{C}$. The reaction medium contained $60 \mu \mathrm{l}$ microsomal fraction, $740 \mu \mathrm{l} 5 \mathrm{mmol}$ $\mathrm{MgCl}_{2} \mathrm{1}^{-1}$ in $0.25 \mathrm{~mol}$ sucrose-phosphate buffer $\mathrm{I}^{-1}$ and $100 \mu \mathrm{l} 0.8 \mu \mathrm{mol}$ NAD $1^{-1}$, and $100 \mu \mathrm{l}\left[{ }^{14} \mathrm{C}\right]$ pregnenolone $(0.3 \mu \mathrm{Ci})$. After aeration with $\mathrm{CO}_{2}$ for $2 \mathrm{~min}$, the reaction was allowed to continue for a further $10 \mathrm{~min}$ at $37^{\circ} \mathrm{C}$ under constant agitation (120 r.p.m.), and was stopped by adding $1 \mathrm{ml}$ of $1 \mathrm{~mol} \mathrm{HCl} 1^{-1}$. Non-reacted substrate and metabolites were removed with two rinses of diethyl ether and dried under a stream of $\mathrm{N}_{2}$.

Pregnenolone was separated from progesterone using silica gel $G$ thin-layer chromatography, with a development solvent of benzene:ethyl acetate (2:1). The scanner confirmed the site of radioactivity on the thin-layer chromatography; progesterone was removed by scraping the resin at this site, followed by hormonal extraction carried out twice with diethyl ether. The radioactivity of the extract was measured with a liquid scintillation counter (Beckman Instruments, CA). As the present assay induced the synthesis of $\left[{ }^{14} \mathrm{C}\right]$ progesterone only from $\left[{ }^{14} \mathrm{C}\right]$ pregnenolone, the quantity of $\left[{ }^{14} \mathrm{C}\right]$ progesterone produced served as an index of $3 \beta$-HSD activity. Enzyme activity was calculated from the percentage of product formed relative to the total radioactive steroid recovered. Recovery after extraction and chromatography was $61.4 \pm 6.2 \%(n=10)$. The intraassay and interassay coefficients of variation in this $3 \beta-\mathrm{HSD}$ activity assay were $8.2 \%$ and $13.7 \%(n=10)$, respectively. The protein concentration in the sample was determined by the method of Lowry (1951), using BSA as the reference protein.

\section{Determination of progesterone, 20a-hydroxyprogesterone and $17 a$-hydroxyprogesterone concentrations}

Progesterone, 20 $\alpha$-hydroxyprogesterone and $17 \alpha$-hydroxyprogesterone concentrations in cotyledons and caruncles were determined by the radioimmunoassay methods of Makino (1973) and Tanemori (1978), with slight modifications. Labelled hormones, $\left[1,2-{ }^{3} \mathrm{H}\right]$ progesterone, $\left[1,2,6,7-{ }^{3} \mathrm{H}\right] 20 \alpha$-hydroxyprogesterone, and $\left[1,2,6,7-{ }^{3} \mathrm{H}\right] 17 \alpha$-hydroxyprogesterone, were purchased from Amersham International (Amersham, Bucks). Antisera against progesterone-3-carboxy methyl oxime-BSA (CMO-BSA), 20a-hydroxyprogesterone-CMO-BSA, and $17 \alpha$-hydroxyprogesterone-3-CMO-BSA were supplied by Teikoku Hormone Mfg Co. (Tokyo). Crossreactivities of the progesterone antiserum were $62.2 \%$ for $5 \alpha$-pregnanedione and $6.3 \%$ for pregnenolone; the crossreactivity of the $20 \alpha$-hydroxyprogesterone antiserum was $5.4 \%$ for $20 \beta$-hydroxyprogesterone, while the crossreactivities of $17 \alpha$-hydroxyprogesterone antisera were $7.9 \%$ for progesterone and $3.2 \%$ for $20 \alpha$-hydroxyprogesterone, respectively.

The gestagen concentrations were determined by subjecting the dried residue of the diethyl ether extract of the homogenized sample $(I-50 \mu \mathrm{l})$ before ultracentrifugation to liquid chromatography elution with a Sephadex LH-20 column, using a mobile phase of hexane:benzene:methanol (82.5:10:7.5, $\mathrm{v}: \mathrm{v}: \mathrm{v})$. The rates of recovery after extraction and chromatography were $92.2 \pm 4.2 \%$ for progesterone, $82.5 \pm 4.0 \%$ for $20 \alpha$-hydroxyprogesterone and $75.1 \pm 3.8 \%$ for $17 \alpha$-hydroxyprogesterone $(n=15)$. The lower limit of accurate quantitation was $10 \mathrm{pg}$ less than that specified in the respective assay procedures for progesterone, 20 $\alpha$-hydroxyprogesterone and $17 \alpha$-hydroxyprogesterone. The intra-assay and interassay ( $n=15$ ) coefficients of variation for progesterone, $20 \alpha$-hydroxyprogesterone and $17 a$-hydroxyprogesterone were $8.2 \%, 9.8 \%$ and $9.2 \%$, and $12.3 \%, 14.8 \%$ and $17.4 \%$, respectively. In determining the interassay and intra-assay coefficients of variation, the concentrations of progesterone, $20 \alpha$-hydroxyprogesterone and $17 \alpha$-hydroxyprogesterone in the control samples $(n=15)$ were $1.54 \pm 0.40,1.05 \pm 0.30$, and $0.51 \pm 0.16 \mathrm{ng} \mathrm{mg}^{-1}$ protein, respectively.

\section{Statistical analysis}

Statistical significance was verified by Duncan's multiple range test and by determining the correlation coefficients for the specific effects of site, month of gestation, and any interaction between these and the concentrations of $3 \beta$-HSD, progesterone, $20 \alpha$-hydroxyprogesterone and $17 \alpha$-hydroxyprogesterone.

\section{Results}

\section{Profile of the method for determining $3 \beta$-HSD activity}

To decide on the sample quantity and the incubation time used, we evaluated the microsomal fraction from the cotyledon tissue during the eighth month of gestation; a linear relationship was obtained with up to $0.55 \mathrm{mg}$ protein and $20 \mathrm{~min}$ (Fig. Ia, b). We therefore used protein samples of about $0.2 \mathrm{mg}$ and an incubation time of $10 \mathrm{~min}$ in this study. The Michaelis constant $\left(K_{\mathrm{m}}\right)$ and the maximum $3 \beta$-HSD reaction velocity $\left(V_{\max }\right)$ for cotyledons during gestation month eight were derived from a Lineweaver-Burk plot of enzyme activity against substrate concentration. The $K_{\mathrm{m}}$ and $V_{\max }$ values in the cotyledons were $100 \mathrm{nmol} \mathrm{I}^{-1}$ and $100 \mathrm{pmol} \mathrm{min}^{-1} \mathrm{mg}^{-1}$ protein, respectively (Fig. Ic).

\section{$3 \beta$-HSD activity in cotyledons and caruncles}

The $3 \beta$-HSD activity in the cotyledons increased significantly $(P<0.05)$ between gestation months 4 and 7 , reached a peak at gestation month 8 , and decreased immediately after parturition. The activity of $3 \beta$-HSD was low in the caruncles throughout the experimental period, and was significantly $(P<0.01)$ lower than in the cotyledons (Fig. 2a).

\section{Progesterone, 20a-hydroxyprogesterone and}

$17 a$-hydroxyprogesterone concentrations in cotyledons and caruncles

The concentrations of progesterone and $20 \alpha$-hydroxyprogesterone in cotyledons are shown (Fig. $2 b, c)$. The coefficients of correlation $(r)$ between $3 \beta$-HSD activity and progesterone, $3 \beta$-HSD activity and $20 \alpha$-hydroxyprogesterone, 
(a)

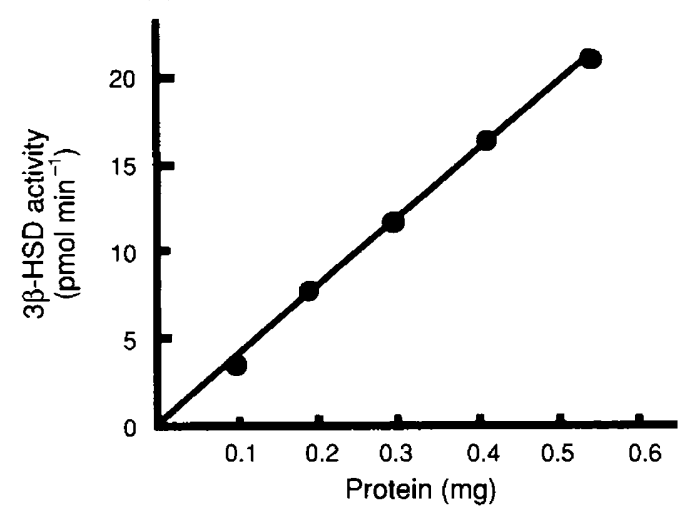

(b)
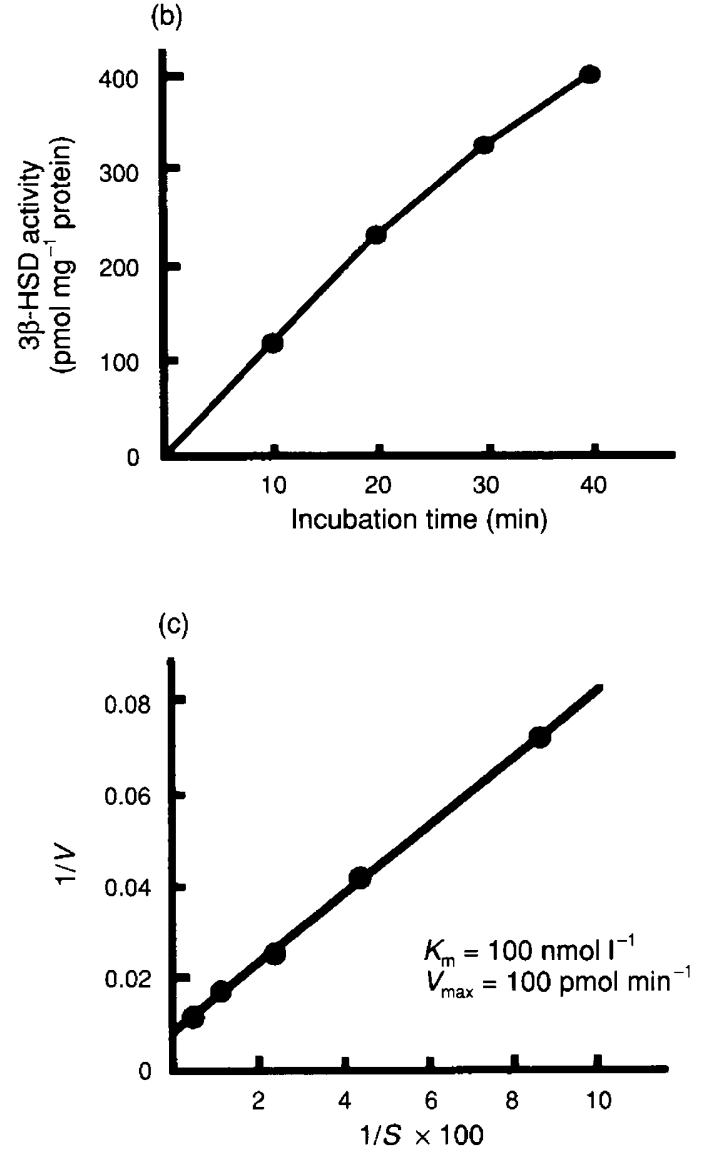

Fig. 1. Characterization of $3 \beta$-hydroxysteroid dehydrogenase (3ß-HSD) activity. (a) Relationship to protein content in the bovine cotyledon during the eighth month of gestation. (b) Relationship to incubation time, using $0.2 \mathrm{mg}$ of the bovine cotyledon during the eighth month of gestation. (c) Lineweaver-Burk plot showing the relationship between bovine placental (microsomal fraction) $3 \beta$-HSD activity $(1 / V)$ and $\left[{ }^{14} \mathrm{C}\right]$ pregnenolone concentration $(1 / S \times 100)$.

and progesterone and 20a-hydroxyprogesterone in cotyledons were $0.811,0.721$ and $0.872(P<0.01)$, respectively. Cotyledons expressed significantly $(P<0.01$ or $P<0.05)$ higher concentrations of progesterone and 20a-hydroxyprogesterone than did caruncles throughout the gestation period.
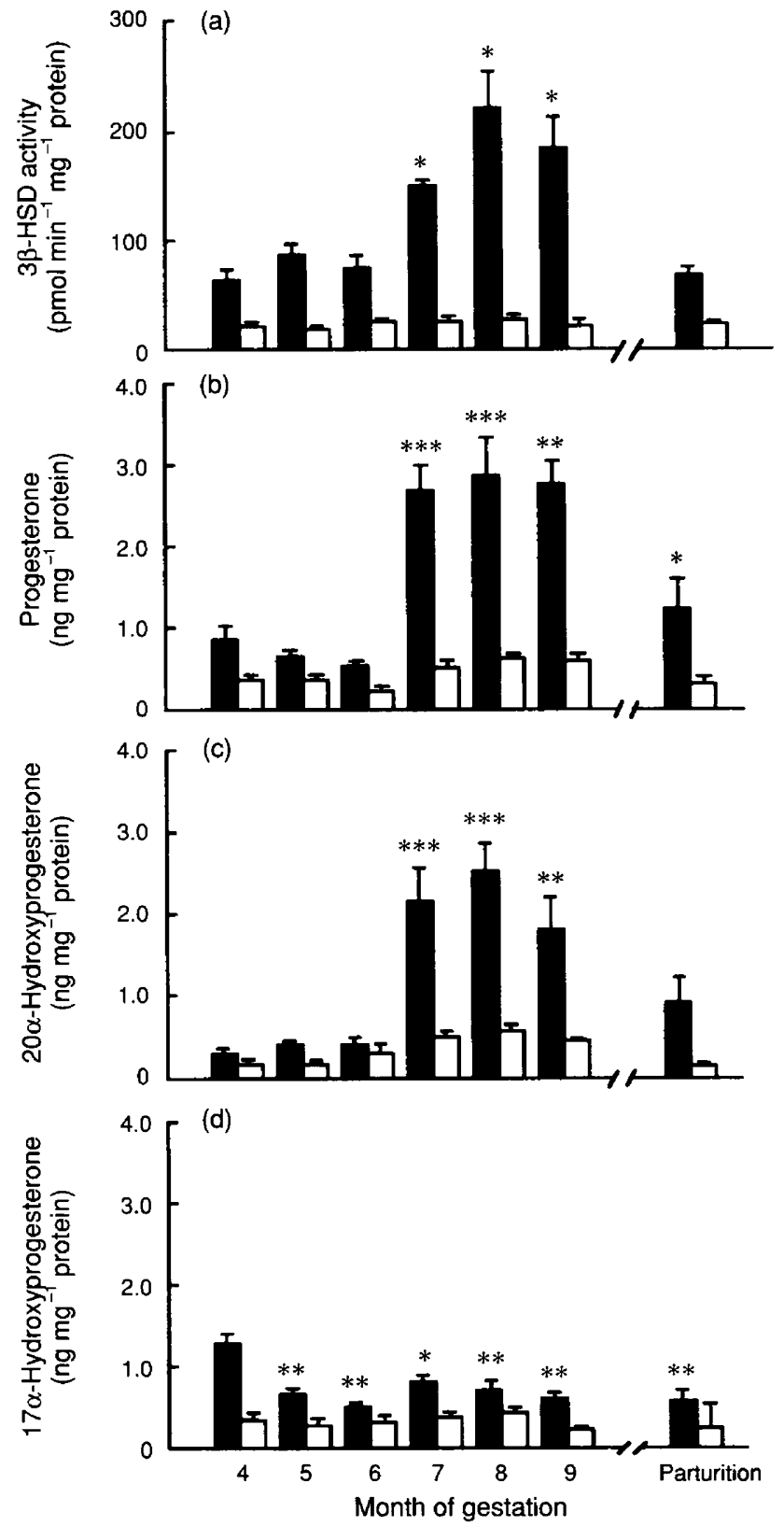

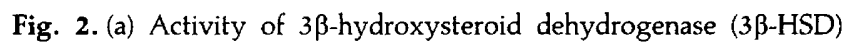

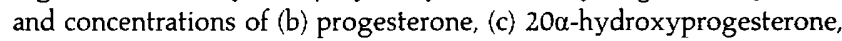
and (d) 17a-hydroxyprogesterone in bovine cotyledons ( $\boldsymbol{\square}$ ) and caruncles $(\square)$ during gestation. Histograms show means \pm SEM. Asterisks indicate significant differences compared with values during month 4 of gestation: ${ }^{*} P<0.05 ;{ }^{*} P<0.01 ; * * P<0.001$.

The concentration of $17 \alpha$-hydroxyprogesterone in cotyledons at gestation months 4 and 5 was significantly $(P<0.01$ or 0.05) higher than that of 20a-hydroxyprogesterone (Fig. $2 \mathrm{~d}$ ); however, from gestation month 7-9, the concentration of $17 a$-hydroxyprogesterone was significantly $(P<0.01$ or 0.05 ) lower than that of progesterone and 20a-hydroxyprogesterone.

In caruncles, progesterone, 20 $\alpha$-hydroxyprogesterone and $17 \alpha$-hydroxyprogesterone concentrations showed no apparent changes throughout the gestation period. 


\section{Discussion}

Documentation of progesterone synthesis in relation to the progress of gestation is limited. Inaba et al. (1983) demonstrated increases in progesterone synthesis from gestation months 7.5-9 in cows; however, only one case per month was sampled. Their finding is similar to the pattern of $3 \beta$-HSD activity in the study reported here. Moreover, in this study, changes in progesterone concentrations in cotyledons were very similar to the fluctuations in $3 \beta-\mathrm{HSD}$ activity. The incidence of miscarriages in pregnant cows luteoectomized after gestation day 200 is low (Estergreen et al, 1967). Our findings have indicated that this phenomenon is probably due to the functional role of progesterone released from the placenta rather than from the maternal adrenals.

We found that $3 \beta$-HSD activity was higher in the bovine cotyledons than in the caruncular placentae. This finding is in agreement with findings that the fetal cotyledon is the primary site of placental progesterone (Conley and Ford, 1987; Gross and Williams, 1988) and oestrogen synthesis (Hoffmann et al., 1976; Tsumagari et al., 1993). We also found that progesterone concentration in caruncles is much lower than that in the cotyledons. Thus, the distribution of progesterone in cotyledons and caruncles appears to differ from that of oestrogen, as there is no significant difference between the concentration of oestrogen in cotyledons and caruncles (Tsumagari et al., 1993), and two-thirds of the samples used in the previous study were also investigated in the study reported here. This difference in the distribution of the two steroids is surprising as the diffusion of steroids should be equal in maternal and fetal directions. In this study, we found that the concentration and fluctuation of 20a-hydroxyprogesterone in the cotyledons throughout the gestation period was very similar to that of progesterone. The ovine fetal placenta has been shown to convert progesterone to 20a-hydroxyprogesterone (Anderson et al., 1975); furthermore, fetal erythrocytes in both sheep and cows have been shown to contain abundant quantities of the enzyme responsible for converting progesterone to 20a-hydroxyprogesterone (Nancarrow, 1983). The conversion of progesterone to $20 \alpha$-hydroxyprogesterone is reported to be a reversible reaction (Nancarrow and Seamark, 1968). Our current and some previous findings (Nancarrow and Seamark, 1968; Anderson et al., 1975; Nancarrow, 1983) indicate that the progesterone produced in the fetal cotyledon is rapidly converted to $20 \alpha$-hydroxyprogesterone before diffusing to the maternal caruncle, which explains why the maternal site has a lower progesterone concentration than does the fetal site. The progesterone concentration in bovine fetal plasma is very low (Challis et al., 1974; Hoffmann et al., 1976). These findings also support the idea that the conversion of progesterone to $20 \alpha$ hydroxyprogesterone occurs in the fetal compartment. A low progesterone concentration in the fetus is beneficial for its development and survival.

Although we found that cotyledons had a relatively high concentration of 17a-hydroxyprogesterone during the fourth month of gestation, there were no subsequent changes in the concentration of this hormone accompanying the progress of fetal development. Moreover, there was no apparent correlation between the concentrations of 17a-hydroxyprogesterone and progesterone, implying that $17 \alpha$-hydroxyprogesterone was probably derived from 17a-hydroxypregnenolone.

Our findings here indicate that increases in placental $3 \beta$-HSD activity persist from gestation month $7-9$, as progesterone synthesized in the cotyledon is converted concurrently to 20a-hydroxyprogesterone before being transferred to the fetal blood during this period.

The authors wish to thank V. L. Estergreen for reading the manuscript. This study was supported, in part, by a Grant-in-Aid for Scientific Research (B) 62480090 from the Ministry of Education, Science and Culture of Japan.

\section{References}

Ainsworth L and Ryan KJ (1967) Steroid hormone transformations by endocrine organs from pregnant mammals. II Formation and metabolism of progesterone by bovine and sheep placental preparations in vitro Endocrinology $\mathbf{8 1}$ 1349-1356

Anderson ABM, Flint APF and Turnbull AC (1975) Mechanism of action of glucocorticoids in induction of ovine parturition: effect on placental steroid metabolism Journal of Endocrinology 66 61-70

Arthur GH, Hoakes DE and Pearson H (1982) Pregnancy and its diagnosis. In Veterinary Reproduction and Obstetrics (5th Edn) pp 49-84 Eds GH Arthur, DE Noakes and H Pearson. Baillière Tindall, London

Challis JRG, Kim CK, Naftolin F, Judd HL, Yen SSC and Benirschke K (1974) The concentrations of androgens, oestrogens, progesterone and luteinizing hormone in the serum of fetal calves throughout the course of gestation Journal of Endocrinology 60 107-115

Comline RS, Hall LW, Lavelle RB, Nathanielsz PW and Silver M (1974) Parturition in the cow: endocrine changes in animals with chronically implanted catheters in the fetal and matemal circulation Journal of Endocrinology 63 $451-472$

Conley A and Ford SP (1987) Effect of prostaglandin $F_{2} \alpha^{-i n d u c e d ~ l u t e o l y s i s ~ o n ~}$ in vitro and vivo progesterone production by individual placentomes of the cow Journal of Animal Science 65 500-507

Erb RE, Estergreen VL, Gomes WR, Plotka ED and Frost OL (1968) Progestin levels in corpora lutea and progesterone in ovarian venous and jugular vein blood plasma of the pregnant bovine Journal of Dairy Science 51 401-410

Estergreen VL, Frost OL, Gomes WR, Erb RE and Bullard JF (1967) Effect of ovariectomy on pregnancy maintenance and parturition in dairy cows Joumal of Dairy Science 50 1293-1295

Ferrell CL, Ford SP, Prior RL and Christensen RK (1983) Blood flow, steroid secretion and nutrient uptake of the gravid bovine uterus and fetus Journal of Animal Science 56 656-667

Gomes WR and Erb RE (1965) Progesterone in bovine reproduction: a review Journal of Dairy Science 48 314-330

Gross TS and Williams WF (1988) In-vitro steroid synthesis by the placenta of cow in late gestation and at parturition Journal of Reproduction and Fertility $\mathbf{8 3}$ 565-573

Hirato K, Yanaihara T and Nakayama T (1982) A study of delta5-3 $\beta$ hydroxysteroid dehydrogenase in human foetal adrenal glands Acta Endocrinologica 99 122-128

Hoffman B, Wagner WC and Gimenez T (1976) Free and conjugated steroids in maternal and fetal plasma in the cow near term Biology of Reproduction 15 $126-133$

Inaba T, Oka A, Koketsu Y, Nakama S and Imori T (1983) Progesterone and estrogen synthesis by the bovine placenta Japanese Journal of Animal Reproduction 29 88-93

Lowry OH, Rowsbrough NJ, Farr AL and Randall RJ (1951) Protein measurement with the folin phenol reagent Journal of Biological Chemistry 193 265-275

Makino T (1973) Radioimmunoassay of plasma sex steroids Folia Endocrinologica Japonica $49629-646$

Nancarrow CD (1983) Decline with age in the rate of production of progesterone to 20a-hydroxypregn-4-en-3-one in the blood of perinatal ruminants Australian Journal of Biological Science 36 183-190

Nancarrow CD and Seamark RF (1968) Progesterone metabolism in fetal blood Steroids 12 367-379 
Reimers TJ, Ullmann MB and Hansel W (1985) Progesterone and prostanoid production by bovine binucleate trophoblastic cells Biology of Reproduction 33 1227-1236

Seki M, Hara $Y$, Sekiya M, Itagaki T, Hirato $K$, Yanaihara $T$ and Nakayama $T$ (1987) Changes in steroid enzyme activity in the human endometrium during the menstrual cycle Acta Obstetrica et Gynaecologica Japonica 39 1571-1578

Shemesh M, Hansel W and Strauss JF (1983) Bovine placentomes contain factors which decrease progesterone secretion Biology of Reproduction 29 856-862 Short RV (1958) Progesterone in blood II. Progesterone in the peripheral blood of pregnant cows Journal of Endocrinology 16 426-428

Stabenfeldt GH, Osburn BI and Ewinf LL (1970) Peripheral plasma progesterone levels in the cow during pregnancy and parturition American Physiology 218 571-575
Tanemori K (1978) The significance of serum 20a-hydroxy-progesterone as determined by radioimmunoassay Bulletin of Nihon University $\mathbf{3 7}$ $1245-1255$

Tsumagari S, Kamata J, Takagi K, Tanemura K, Yosai A and Takeishi M (1993) Aromatase activity and oestrogen concentrations in bovine cotyledons and caruncles during gestation and parturition Journal of Reproduction and Fertility $98631-636$

Wendorf GL, Lawyer MS and First NL (1983) Role of the adrenals in the maintenance of pregnancy in cows Journal of Reproduction and Fertility 68 281-287

Wiener M (1976) Control of placental 3 3 -hydroxy-5-steroid dehydrogenase Comparison of enzyme characteristics in man, cow, goat, rat and rhesus monkey Biology of Reproduction 14 306-313 